\title{
FRESHWATER FISH FAUNA OF THE RIVERS MULA AND MUTHA, PUNE, MAHARASHTRA
}

\author{
G.K. Wagh and H.V. Ghate ${ }^{1}$ \\ Modern College, Shivajinagar, Pune, Maharashtra 411005, India. \\ ${ }^{1}$ Corresponding author;Email: hemantghate@yahoo.com
}

\begin{abstract}
There are, at present, at least 62 species of fish in the Mula and Mutha Rivers flowing through Pune. Sewage and industrial pollution of river waters, besides prevalence of exotic fish, appear to be the reasons for the depletion of fish species. About 30\% (18 out of 61) of the fish species, that were reported earlier, were not found during this survey. Nineteen species that were not known in 1940s were found in this survey.
\end{abstract}

\section{Keywords}

Fishes, Mula-Mutha Rivers, Pune, Maharashtra

\section{Introduction}

In 1942 a series of papers dealing with the fish species found in Poona (now Pune) appeared in the Journal of the Bombay Natural History Society (Fraser, 1942; Hora \& Misra, 1942; Suter, 1944). Of these, Fraser's paper also gave considerable details regarding Mula and Mutha rivers and their environs, a description that is still quite valid in many respects. Actually, Fraser's collection is of 1936-1937 and it was the same collection that was studied by Hora and Misra (1942) later.

To assess the present status of fish species known from the Mula and Mutha Rivers, we undertook a survey of the same rivers in 1992. Preliminary observations of our findings were presented in the first National Symposium on Environmental Hydraulics at Pune (Ghate et al., 1992) and published in its proceedings. We continued collecting and studying fishes from the rivers Mula and Mutha and are presenting here a complete list of fishes collected during the three-year period (1992-95). This will provide the basic qualitative data regarding fish diversity of the two rivers flowing through the city.

\section{Materials and Methods}

Fishes were collected from the rivers Mula and Mutha with the help of local fishermen. Fish markets were also regularly visited and the common species noted. The river Mutha was surveyed at many places from the Khadakwasla Dam until its confluence with the river Mula. Mula River was surveyed from PimpriChinchwad area up to the confluence. Mula-Mutha River was sampled for about $2 \mathrm{~km}$ after the confluence (Fig. 1). All fishes were properly preserved in $10 \%$ buffered formalin for further study. Identification was based on the keys by Jayaram (1981, 1991), Menon (1987), and, Talwar and Jhingran (1991).

We have taken Hora and Misra's list of 1942, and also the additions made by Suter (1944), as the basis of comparison because these are complete, authentic and earliest lists of fishes of the Mula and Mutha with specific locality data. We have also checked the lists published by Tonapi and Mulherkar (1963) and Tilak and Tiwari (1976). In the former there are 60 species listed (mainly from Mula and Mutha rivers) while in the latter there are 112 species listed from all over Pune District (without mentioning the rivers and places surveyed). Gazetteer of the former Bombay State (Palande, 1954) also includes a record of fishes from Pune District (it mentions 70 species from Mula, Mutha, Bhima and other water bodies). In any case, fish fauna of Mula and Mutha has not been studied in the last 30 years. Even the paper by Tilak and Tiwari (1972) is based on collections made in the early sixties. The present attempt was made to find out if the much evident pollution and other ecological changes have affected riverine biota in general and fish in particular. The present paper is based on collections made during 1992-95.

\section{Results and Discussion}

From the list presented in this paper (Table 1), it is apparent that there are, at present, at least 62 species of fish in the Mula and Mutha rivers. The lists of Hora and Misra (1942) and Suter (1944) together include 61 species of fish as occurring in Mula and Mutha. Of these 61 species 18 were not found during this 
Table 1. List of fishes from Mula and Mutha

\begin{tabular}{|c|c|}
\hline Scientific name & Remarks \\
\hline $\begin{array}{l}\text { Osteoglossiformes } \\
\text { Notopteridae } \\
\text { Notopterus notopterus Pallas }\end{array}$ & + \\
\hline \multicolumn{2}{|l|}{ Cypriniformes } \\
\hline Catla catla (Hamilton-Buchanan) &,$- \mathrm{C}$ \\
\hline Cirrhinus fulungee (Sykes) & + \\
\hline Cirrhinus mrigala mrigala (Hamilton-Buchanan) &,$- \mathrm{C}$ \\
\hline Cirrhinus reba (Hamilton-Buchanan) & + \\
\hline Cyprinus carpio Linnaeus & $-, \mathrm{C}, \mathrm{E}$ \\
\hline Gonoproktopterus kolus & + \\
\hline Gonoproktopterus thomassi (Day) & - \\
\hline Labeo ariza (Hamilton-Buchanan) & - \\
\hline Labeo boggut (Sykes) & + \\
\hline Labeo calbasu (Hamilton-Buchanan) & + \\
\hline Labeo porcellus (Heckel) & + treated as $=L$. potail \\
\hline Labeo rohita (Hamilton-Buchanan) &,$- \mathrm{C}$ \\
\hline Osteobrama cotio peninsularis Silas & $\begin{array}{l}\text { - ? identified as } \\
\text { O.c.cunma }\end{array}$ \\
\hline Osteobrama neilli (Day) & + \\
\hline Osteobrama vigorsii (Sykes) & + \\
\hline Osteochilichthys nashii (Day) & + \\
\hline Puntius amphibius (Valenciennes) & + \\
\hline Puntius chola (Hamilton-Buchanan) & + \\
\hline Puntius jerdoni (Day) & + \\
\hline Puntius sarana subnasutus (Valenciennes) & - \\
\hline Puntius sophore (Hamilton-Buchanan) & - \\
\hline Puntius ticto (Hamilton-Buchanan) & + \\
\hline Rohtee ogilbii Sykes & + \\
\hline Salmostoma boopis (Day) & + \\
\hline Salmostoma novacula (Valenciennes) & + \\
\hline \multicolumn{2}{|l|}{ Cyprinidae, Danioninae (=Rasborinae) } \\
\hline Amblypharyngodon mola (Hamilton-Buchanan) & - \\
\hline Barilius bendelisis (Hamilton-Buchanan) & + \\
\hline Danio aequipinnatus (McClelland) & + \\
\hline Danio devario (Hamilton-Buchanan) & - \\
\hline Rasbora daniconius (Hamilton-Buchanan) & + \\
\hline \multicolumn{2}{|l|}{ Cyprinidae, Garrinae } \\
\hline Crossocheilus latius latius Hamilton-Buchanan & + \\
\hline Garra mullya (Sykes) & + \\
\hline \multicolumn{2}{|l|}{ Parapsilorhynchidae } \\
\hline Parapsilorhynchus tentaculatus Annandale & + \\
\hline \multicolumn{2}{|l|}{ Balitoridae, Nemacheilinae } \\
\hline Nemacheilus anguilla (Annandale) & + \\
\hline Schistura denisoni denisoni (Day) & - \\
\hline Acanthocobitis moreh (Sykes) & + \\
\hline Nemachilichthys ruppelli (Sykes) & + \\
\hline \multicolumn{2}{|l|}{ Cobitidae, Cobitinae } \\
\hline
\end{tabular}

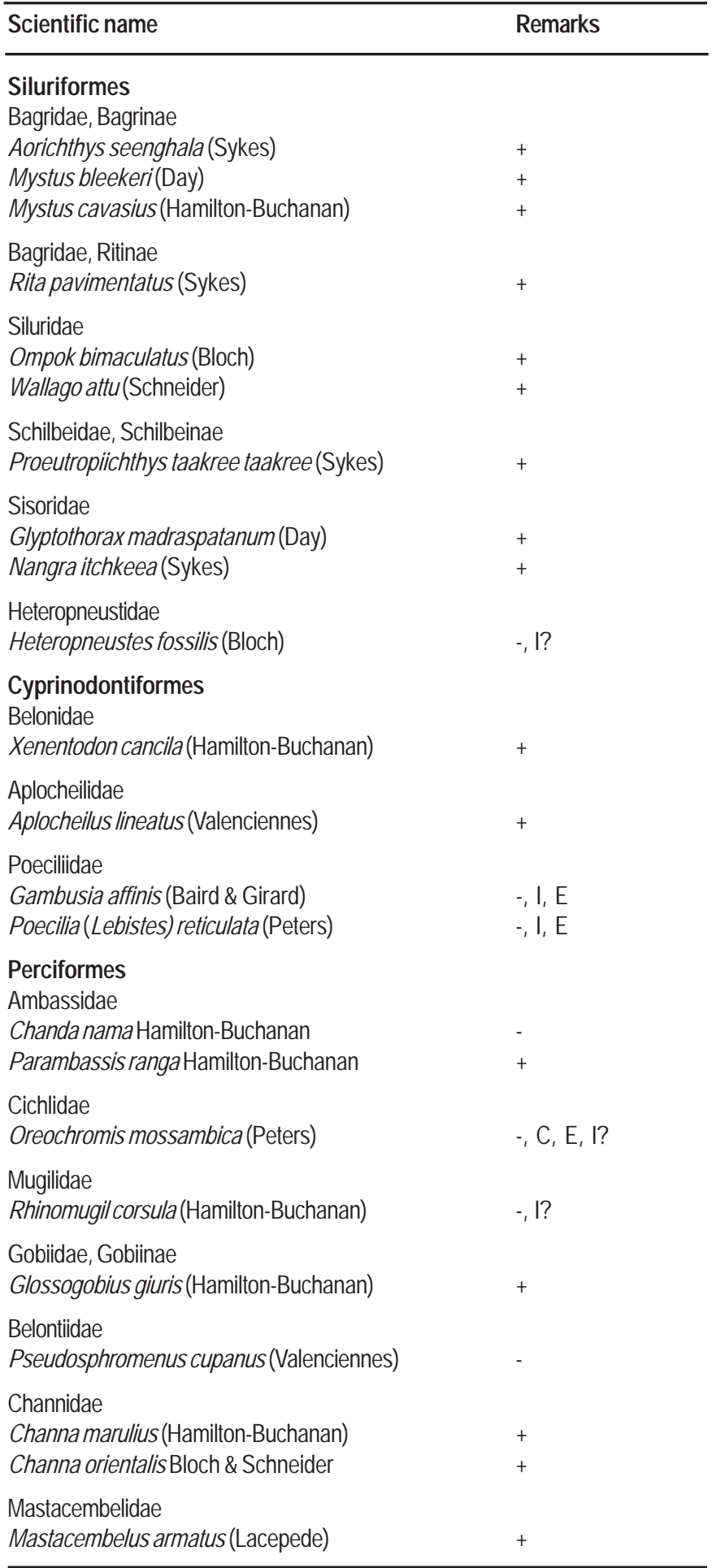

+ = species also reported in Hora-Misra \& Suter's papers; $C$ = cultivated fish species, not native to this river; $E$ = exotic species; I = introduced purposely; I? = source of introduction unknown; - = species not reported in Hora-Misra and Suter's papers.

Nomenclature after Jayaram, 1999 


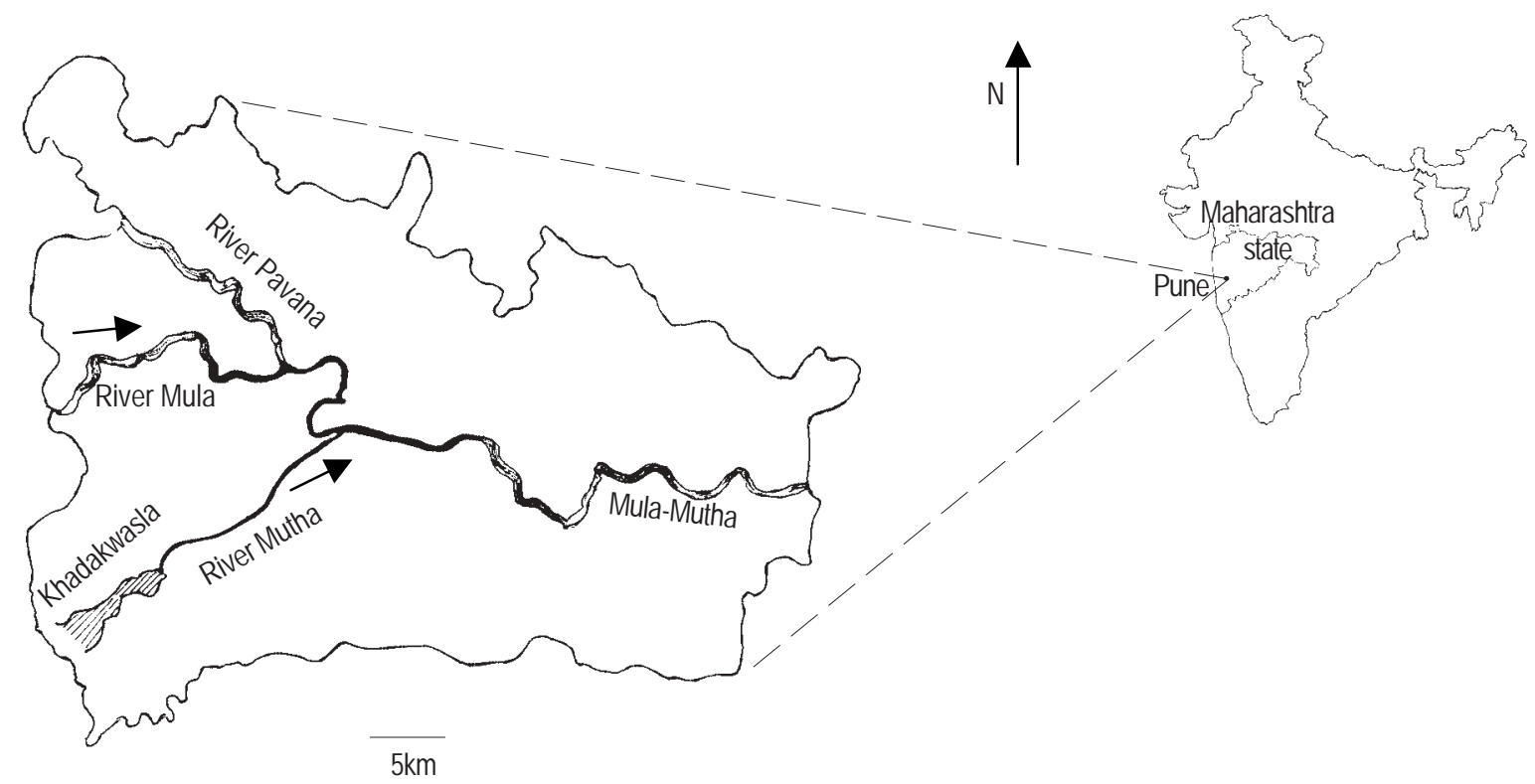

Figure 1. Map of Pune region showing rivers Mula, Mutha and Pavana. The shaded area denotes parts of the rivers that were surveyed intensively for fish.

study. Of these 43 species reported now, some species were recorded from these water bodies nearly 150 years ago by Sykes during 1839-41. It appears that these species are not yet affected by pollution and associated changes in water quality. Some of the species described by Sykes are: Garra mullya, Rohtee ogilbii, Nemachilichthys ruppelli, Proeutropiichthys takree and Labeo boggut and these are still quite common in MulaMutha. The 'lost' 18 include large fishes like Tor khudree, Silonia childreni, Anguilla bengalensis, Barilius barna, Schismatorhynchos (Nukta) nukta, Salmostoma clupeoides, Labeo fimbriatus, Labeo potail, Ompok pabo, Mystus gulio, Glyptothorax conirostrae poonaensis, G. lonah, and Oreonectes (Oreonectes) evezardi. Thus, although we have presented a list of 62 fishes from Mula and Mutha rivers, about 30\% of the fish species reported in 1940s by Hora and Misra, and Suter were not found during this survey. Our list of 62 fishes also includes 19 species that were not known in 1940s (though some of these were reported later by others). Fishes like Rhinomugil corsula and Pseudosphromenus cupanus, however, were reported by us for the first time (table 1).

The main reason for this change (loss of some fish species and hence fish diversity) could be due to massive sewage and industrial pollution released into these rivers. River Mutha is so much loaded with sewage that, except during heavy monsoon rains, the flowing water is almost raw sewage. The area of the confluence of the two rivers is practically choked with decaying organic matter. Bubbles of methane and other gases erupting at the surface are testimony to this statement. The River Mutha, from Vitthalwadi downstream, up to its confluence with Mula, is almost an open drainage now. Tonapi and Mulherkar (1963) have made similar comments earlier. At many places there are dense assemblages of tubificid worms and chironomid larvae (enormous populations of these animals are known as indicators of sewage pollution). However, at many places near Khadakwasla dam, both above and below the actual dam site, the water is clear and apparently unpolluted.

On the other hand, river Mula passes through industrial and densely populated surroundings. As a result it is polluted with industrial effluents as well as civic wastes. Though not frequently, fish kills have been observed at many places in this river during 1976-84 (Ghate, pers. obser.). Soon after monsoon, river Mula is practically choked with water hyacinth for as many as six months of the year. Various control measures, including biological methods, have thus far proved ineffective in combating this weed. Fortunately, it has not yet penetrated into the river Mutha where only a few patches of water hyacinth are observed.

Both, physico-chemical parameters and aquatic weeds occurring in these two rivers have been studied (Pawar et al., 1992; Wagh, 1999). All the data collected so far indicate that the rivers are loaded with organic matter. There is very little dissolved oxygen and, in many places, submerged aquatic vegetation (mainly 


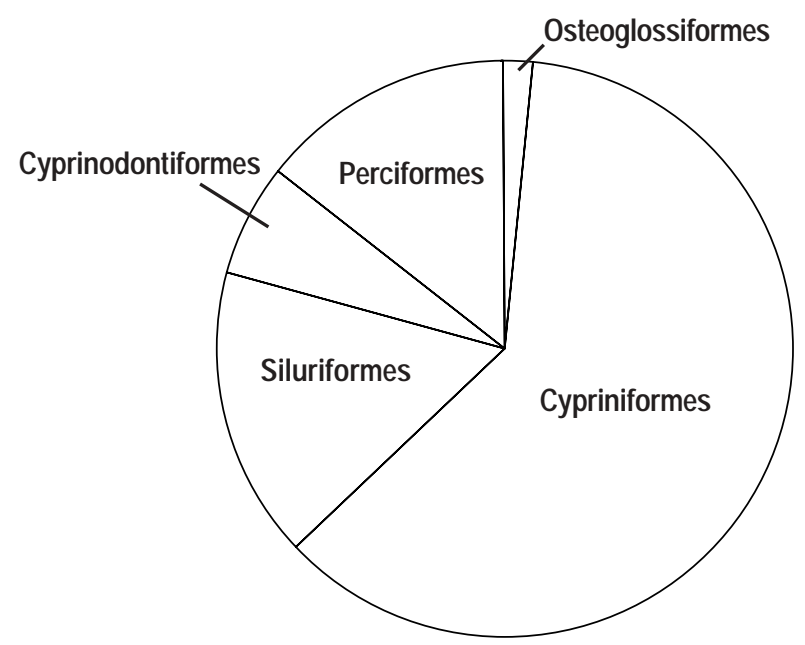

Figure 2. Percent representation of different orders of fishes in Mula and Mutha rivers

Hydrilla, Potamogeton and Vallisneria) chokes the river. We have also reported a hitherto unreported emergent aquatic weed - the alligator weed Alternanthera philoxeroides from the river Mutha (Wagh et al., 1995).

The incoming wastes of different kinds has totally changed or destroyed habitat necessary for survival and reproduction of certain fishes. That pollution is responsible for habitat destruction in aquatic ecosystems has been amply documented by many workers. This, we believe, is the main reason for reduction in number of species. Direct effects of pollutants on fishes (such as effect on reproduction) are also likely, but we have no data. Regarding the fishes that are newly found, we have already reported Macropodus (now known as Pseudosphromenus) cupanus (Ghate \& Wagh, 1991) and Rhinomugil corsula (Ghate \& Wagh, 1995). We also published photographs and description of the colour pattern of juveniles of Rohtee ogilbii and showed how the pattern is almost lost in larger fish (Ghate \& Wagh, 1994). Heteropneustes fossilis is also becoming quite common now, especially in sewage-polluted areas; obviously because of its air breathing habits it can withstand such low oxygen conditions. We do not have any idea as to whether its introduction is purposeful or accidental. Same is the case with Oreochromis. These four species were not reported by Hora and Misra, and Suter as well as later workers mentioned earlier. These species appear to be recent introductions.

Two exotic fishes Oreochromis and Gambusia are practically everywhere. Gambusia was introduced for mosquito control (and probably Lebistes also came along) but Oreochromis could be an accidental introduction from cultivation tanks. What effects these exotic fishes may have on the native fish fauna is difficult to predict at present. There are already differences of opinion about Oreochromis. The strongest argument against Oreochromis culture is related to its prolific breeding and consequent over-population, resulting in severe competition with other species and threat to aquatic vegetation (Saxena, 1988).

With respect to Gambusia, we have noticed that it affects the populations of Aplocheilus lineatus. It was observed that Aplocheilus was a very common denizen of the shallow, marginal stretches of the river Mutha during 1975-80, when Gambusia was not very common (Ghate, unpublished data). After 1980 Aplocheilus became quite rare until about 1990. Its place was taken by Gambusia, which is a prolific breeder. But again, since 1990, Aplocheilus is being regularly observed and its population is perhaps slowly recovering. It is likely that Gambusia and Aplocheilus, because of their similar ecological niche and active surface feeding, compete with one another. However, Gambusia is viviparous while Aplocheilus is oviparous. It is likely that Aplocheilus has now overcome the initial suppressive action exerted by Gambusia. Unfortunately, we do not have any quantitative data regarding either of these species but it is certain that Gambusia far outnumber Aplocheilus, even today. Gambusia also appears to be more tolerant of pollution (hence at an advantage) than Aplocheilus. We therefore feel that alien species must be carefully watched and their effects on native fish must be investigated in detail. We also feel that rigorous pollution control will improve the situation in rivers as healthy populations of fish are still present in a few restricted locations along the length of the rivers.

\section{Acknowledgements}

The authors are grateful to the authorities of India Foundation, Pune, for providing financial assistance during the early phase of this survey. Dr. K.C. Jayaram helped in taxonomy, made valuable suggestions and, above all, encouraged us; we are indebted to him. We also received help from the late Dr. A.G.K. Menon, to whom we shall remain grateful. We would also like to record our sincere thanks to the authorities of Modern College for providing the necessary facilities to carry out this work.

\section{References}

Fraser, A.G.L. (1942). Fish of Poona - Part I. Journal of the Bombay Natural History Society 43: 79-91.

Ghate, H.V. and G.K. Wagh (1991). First record of the belontid fish Macropodus cupanus Valenciennes from Pune, Maharashtra. Journal of the Bombay Natural History Society 88: 124-125.

Ghate, H.V., G.K. Wagh and S.L. Lokhande (1992). Fish fauna of the rivers Mula and Mutha, Pune. Proceedings of the First National Symposium on Environmental Hydraulics, CWPRS, Pune.

Ghate, H.V. and G.K. Wagh (1994). On the colouration of Rohtee ogilbii Sykes (Pisces: Cyprinidae: Cyprininae). Journal of the Bombay Natural History Society 91: 326-327. 
Ghate, H.V. and G.K. Wagh (1995). Additional information on the grey mullet Rhinomugil corsula (Hamilton) (Pisces: Mugilidae) from western Maharashtra. Journal of the Bombay Natural History Society 92: 273-274.

Hora, S.L. and K.S. Misra (1942). Fish of Poona - Part II. Journal of the Bombay Natural History Society 43: 218-225.

Jayaram, K.C. (1981). The Freshwater Fishes of India, Pakistan, Bangladesh, Burma and Sri Lanka - A Handbook. Zoological Survey of India, Calcutta, 475pp.

Jayaram, K.C. (1991). Revision of the genus Puntius Hamilton from the Indian region (Pisces: Cypriniformes: Cyprinidae: Cyprininae). Records of Zoological Survey of India, Occasional Paper No. 135, Zoological Survey of India, Calcutta, 178pp.

Jayaram, K.C. (1999). The Freshwater Fishes of the Indian Region. Narendra Publishing House, New Delhi, 551pp.

Menon, A.G.K. (1987). Fauna of India and the adjacent countries. Pisces 4 (part I), Homalopteridae. Zoological Survey of India, Calcutta. Palande, M.R. (1954). Gazetteer of Bombay State (revised edition), District series - Vol. 20, Poona District.

Pawar, N.J., H.R. Wagh, G.K. Wagh and U. Nagpal (1992). Winter water quality variations in the river Mutha flowing through Pune city, Maharashtra. Proceedings, First National Symposium on Environmental Hydraulics, CWPRS, Pune.
Saxena, B.S. (1988). Culture of Tilapia in India - a policy issue, pp. 39-40. Proceedings, the First Indian Fisheries Forum. Asian Fisheries Society, Indian Branch, Mangalore.

Suter, M. (1944). New records of fish from Poona. Journal of the Bombay Natural History Society 44: 408-414.

Sykes, W.H. (1841). On the fishes of Dukhun. Transactions of the Zoological Society of London 2: 349-376.

Talwar, P.K. and A.G. Jhingran (1991). Inland Fishes (Vol. I \& II). Oxford IBH, New Delhi, 1158pp.

Tilak, R. and D.N. Tiwari (1976). On the fish fauna of Poona district (Maharashtra). Newsletter of the Zoological Survey of India 2: 193199.

Tonapi, G.T. and L. Mulherkar (1963). Notes on the freshwater fauna of Poona, Part I - Fishes. Proceedings of the Indian Academy of Science 58B(4): 187-197.

Wagh, G.K. (1999). Study of fish, macroinvertebrate and aquatic angiosperm biodiversity of the river Mutha. Ph.D. Thesis, University of Pune (unpublished).

Wagh, G.K., H.V. Ghate and V.S. Ghate (1995). First record of the alligator weed, Alternanthera philoxeroides (Mart.) Griseb. from Pune, Maharashtra. Journal of the Bombay Natural History Society 92: 141143. 